\title{
Sürdürülebilir Eğitim Yapılarında Konfor Koşullarına İlişkin Kullanıcı Görüşleri
}

\author{
Zeynep YANILMAZ D 1, Filiz TAVŞAN D 1* \\ ${ }^{1}$ Karadeniz Teknik Üniversitesi, Mimarlık Fakültesi, Trabzon \\ Geliş Tarihi (Received): 26.04.2021, Kabul Tarihi (Accepted): 28.05.2021 \\ $\square$ Sorumlu Yazar (Corresponding author ${ }^{*}$ ): ftavsan@hotmail.com \\ (C) +904623771675 등 +904623255588
}

\section{ÖZ}

Eğitim yapıları, hayatımızda son derece önemli etkilere sahip yapı grupları arasındadır. Beyin gelişiminin çevresel faktörlerle şekillendiği temel eğitim döneminde, eğitim yapılarının kalitesi çocukların öğrenme deneyimi üzerinde son derece önemli bir rol oynamaktadır. Sürdürülebilir bir okul sunduğu fiziksel olanaklar ile öğrencilere konforlu bir eğitim ortamı sunarken aynı zamanda ekonomik ve çevresel yarar sağlamaktadır. Eğitim yapıları özelinde sürdürülebilir uygulamaların ortaya koyulduğu bu çalışmada amaç; kullanıcı görüşleri bağlamında sürdürülebilir eğitim yapılarının iç mekan konfor koşullarını incelemektir. Bu amaçla İstanbul ilinde bulunan LEED sertifikasına sahip Bahçeşehir Cihangir Koleji ve Terakki Vakfı Okulu'nda öğrenci ve öğretmenlere yönelik bir anket çalışması yapılmıştır. Anket soruları hazırlanırken LEED sertifikasının iç mekan konfor düzeyini iyileştirmek için geliştirdiği iç ortam hava kalitesine ilişkin standartlar baz alınmıştır. Bu bağlamda hazırlanan anket soruları incelenen okulların; iç hava kalitesi, ısıl konfor, işitsel konfor ve görsel konfor koşullarını kullanıcı açısından sorgulamaktadır. Anketlerden elde edilen veriler ışığında okulların mevcut fiziksel durumuna ilişkin değerlendirmeler yapılarak sürdürülebilirlik kriterlerinin uygulanması noktasında olumlu ve olumsuz yönler vurgulanmıştır.

Anahtar Kelimeler: Konfor koşulları, LEED sertifikası, sürdürülebilirlik, temel eğitim yapıları

\section{User Opinions on Comfort Conditions in Sustainable Educational Buildings}

\begin{abstract}
Educational buildings are among the building groups that have an extremely important impact on our lives. In the primary education period when brain development is shaped by environmental factors, the quality of educational buildings plays an extremely important role in children's learning experience. A sustainable school provides students with a comfortable education environment with the physical facilities it offers, while at the same time providing economic and environmental benefits. The aim of the study, in which sustainable practices specific to educational buildings are put forward; to examine the indoor comfort conditions of sustainable education buildings in the context of user opinions. For this purpose, a survey was conducted for students and teachers in Bahçeşehir Cihangir College and Terakki Foundation School, which has LEED certificate in Istanbul. While preparing the survey questions, the standards regarding indoor air quality developed by the LEED certificate to improve the indoor comfort level were taken as basis. The survey questions prepared in this context are; questions indoor air quality, thermal comfort, auditory comfort and visual comfort conditions. In the light of the data obtained from the surveys, evaluations regarding the current physical condition of the schools were made and the positive and negative aspects of the implementation of the sustainability criteria were emphasized.
\end{abstract}

Keywords: Comfort conditions, LEED certificate, sustainability, basic education buildings 


\section{Giriş}

19. yüzyıl başlarında yaşanan teknolojik gelişmeler üretim ve tüketim kültüründe de birtakım değişikliklere yol açmıştır. Seri üretime geçilmesiyle birlikte artan tüketim anlayışı doğal kaynakların hesapsızca kullanılmasına ve nihayetinde tükenme tehlikesiyle karşı karşıya kalmasına neden olmuştur. Kentlerin kontrolsüzce büyümesi ve sanayileşme oranının artması ile birlikte kent nüfuslarında da büyük bir artış yaşanmıştır. Bu gelişmeler neticesinde yeryüzü, insanoğlunun neden olduğu geri dönülemez tahribatlara maruz kalmıştır. Ortaya çıkan çevresel problemler ve yenilenemeyen enerji kaynaklarında meydana gelen azalmalar doğaya karşı sorumluluğumuzu hatırlamamızda etkili olmuş ve ekolojik bir bilinçlenme hareketinin başlamasına neden olmuştur.

Sürdürülebilirlik kavramı ve çevre sorunlarına ilişkin tartışmalar ilk olarak 1971 yılında İsviçre'de bir grup uzman tarafından yürütülen panelde gündeme getirilmiştir. Bu panel sonrasında çevre problemlerine gerekçe olarak sanayileşmiş ülkelerin üretim ve tüketim yapısındaki sorunlar gösterilmiştir (Sev, 2009). 1972 yılında Stockholm'de yapılan "İnsan ve Çevre" konferansından sonra Stockholm Çevre Bildirgesi yayımlanmış bunu da 1976'daki Barcelona Sözleşmesi izlemiştir (Erdede ve ark., 2014). Sürdürülebilirliğin günümüzdeki tanımı ise 1987 yılında Dünya Çevre ve Kalkınma Komisyonu tarafından yayınlanan "Ortak GeleceğimizOur Common Future" adlı raporda yer almıştır. Bu rapora göre sürdürülebilirlik, "Bugünün gereksinim ve beklentilerini, gelecek kuşakların kendi gereksinimlerini karşılama olanaklarını tehlikeye atmaksızın karşılamaktır" şeklinde tanımlanmaktadır. Gilman'a (1992) göre ise sürdürülebilirlik; bir toplumun, bir ekosistemin veya faaliyet gösteren herhangi bir sistemin bağlı olduğu temel kaynakların tükenmesine izin vermeden belirsiz bir geleceğe kadar varlığını devam ettirmesidir. Owen ve Dovey (2008) ise sürdürülebilirliği, mimari gibi kurumsal sınırları olan bir alandan ziyade mimarlık, mühendislik, kentsel planlama, ekoloji, klimatoloji gibi birçok mesleki disiplini bir araya getiren bir söylem olarak kabul etmektedir.

Doğal kaynakların tükenmesi hususunda yapı sektörünün de önemli bir paya sahip olması nedeniyle yapı üretiminin ve yapı yaşam döngüsünün daha az zararla tamamlanabilmesini amaçlayan 'sürdürülebilir mimarlık' terimi ortaya atılmıştır. Sev'e (2009) göre sürdürülebilir mimarlık,

"Iç̧inde bulunduğu koşullarda ve varlığının her döneminde gelecek nesilleri de dikkate alarak, yenilenebilir enerji kaynaklarının kullanımına öncelik veren, çevreye duyarlı, enerjiyi, suyu, malzemeyi ve bulunduğu alanı etkin şekilde kullanan, insanların sağlık ve konforunu koruyan yapılar ortaya koyma faaliyetlerinin tümüdür".

Özellikle 2000'li yıllardan sonra Avrupa ve Amerika ülkelerinde sürdürülebilir mimarlık uygulamalarına sıkça rastlamak mümkündür. Bu örneklerin çevresel performanslarının profesyonel olarak değerlendirilmesi ve sonrasında yapılacak sürdürülebilir yapı uygulamalarına referans sağlaması açısından sertifika programları geliştirilmiştir. Geliştirilen bu sertifika programları, denetlenebilir ortak birtakım kriterleri baz alarak binanın çevresel performansını ortaya koymayı ve yapı sektöründe yeşil bina olanaklarını talep edilir hale getirerek çevre bilincinin arttırımasını teşvik etmeyi amaçlamaktadır (Ding, 2008). Dünya genelinde gelişmiş ve gelişmekte olan ülkelerin birçoğu bölgesel ve ekonomik özellikleri doğrultusunda sertifika programları oluşturmaktadır.

Bina değerlendirme sistemlerine ilk örnek, 1990 yılında İngiltere tarafından geliştirilen BREEAM (Building Research Establishment Environmental Method) sertifikasıdır. Sürdürülebilir bina uygulamalarını arttırmayı amaçlayan BREEAM sertifikasını, 1998 yılında Amerika'da benzer hedefler doğrultusunda oluşturulan LEED (Leadership in Energy and Environmental Design) sertifika sistemi izlemiştir (Saka, 2011). Dünya genelinde olduğu gibi Türkiye'de de LEED ve BREEAM en çok kabul gören ve uygulanan sertifika sistemleridir.

LEED sertifikası, yeşil binaların teşvik edilmesi, üretim hızının arttırılması ve çevresel sürdürülebilirliğe katkı sağlamak amacıyla geliştirilmiştir. Temelde, tasarım sürecinden başlayıp yapım, üretim ve kullanım aşamasını da kapsayan yaşam döngüsü boyunca binaların çevreye olan zararlı etkilerini en aza indirgemeyi hedeflemektedir. LEED'in farklı bina türleri için geliştirdiği farklı sertifika türleri ve kriterleri bulunmaktadır. Bu kriterlerin her birinin puan karşılığı olmakla birlikte alınan puana göre sertifika derecesi de değişmektedir. Bu bağlamda puanlara göre verilen sertifika dereceleri aşağıdaki gibidir:

- 40-49 puan arası Sertifikalı (Certified)

- 50-59 puan arası Gümüş (Silver)

- 60-79 puan arası Altın (Gold)

- 80 ve üzeri puan Platin (Platinum)

LEED sertifika programı başlangıçta yalnızca "Yeni Yapılar" kategorisinde değerlendirme yaparken za- 
manla neredeyse tüm bina türlerini değerlendirme kapsamına almıştır. Günümüzde LEED kapsamında; Bina Tasarım ve İnşaatı (LEED BD+C), İç Mekân Tasarım ve İnşaatı (LEED ID+C), Mevcut Bina Onarım ve Bakımı (LEED O+M), Mahalle Geliştirme (LEED ND), Şehirler ve Topluluklar (LEED for Cities) ve Yeniden Sertifikalandırma (LEED Recertification) kategorileri altındaki tüm yapı grubu ve alanları değerlendirmeye alınmaktadır (URL-1, 2021).

Bu çalışmaya da konu edilen eğitim yapıları, Bina Tasarım ve İnşaatı (LEED BD+C) kategorisinde yer almaktadır. Bu kategori altındaki kredi başlıkları tüm bina türleri için de geçerli olmakla birlikte yalnızca alt kriterler ve puan değerleri değişkenlik göstermektedir. LEED sertifikasının tüm bina türlerini değerlendirdiği kredi başlıkları; konum ve ulaşım, sürdürülebilir sahalar, su verimliliği, enerji ve atmosfer, malzeme ve kaynaklar, iç mekan kalitesi ve diğer olmak üzere 7 başlık altında toplanmaktadır. Her başlık altında oluşturulan alt kriterler bulunmakta ve bu kriterlerden puan alabilmek için öncelikle gerekli görülen koşulların sağlanması gerekmektedir (URL-1, 2021).

Bu çalışmaya LEED sertifikası almış temel eğitim okulları (ilkokul ve ortaokul) dahil edilmiştir. Çalışmanın amacı; kullanıcı görüşleri bağlamında sürdürülebilir eğitim yapılarının iç mekan konfor koşullarını incelemektir.

\section{İç Mekân Konfor Koşulları}

Konfor, yaşam standartlarının kullanıcıların rahatığı ve refahına uygun olması durumudur (Sirel, 1994). Sürdürülebilirlik yaklaşımlarının iç mekanlarda uygulanması noktasında konfor koşulları özellikle ele alınması gereken kriterler arasındadır. Bu çalışma kapsamında iç mekan konfor koşulları; iç ortam hava kalitesi, ısıl konfor, işitsel konfor ve görsel konfor başlıkları altında ele alınmaktadır.

\section{İç Ortam Hava Kalitesi}

İç ortam hava kalitesi, bireylerin sağlıklı ve üretken olabilmesi için mekânın optimum düzeyde hava kalitesine sahip olması durumudur (Schramek, 1999). İç ortam havası da dış ortam havası gibi oksijen, hidrojen, karbondioksit, neon, helyum, ozon gibi birtakım gazları içinde barındırmaktadır. İç hava kalitesi bu gazların oranlarına bağlı olarak değişkenlik göstermektedir. İnsanlarda sağlık sorunlarına ve memnuniyetsizliğe neden olmayan iç hava koşulları ideal olarak nitelendirilmektedir (Yüksek ve ark., 2015).
İç ortam hava kalitesini etkileyen yapı içi ve dışından kaynaklı pek çok kirletici bulunmaktadır. Yapı içi kirleticilere; dış ortamdaki gazlar, buharlar, mikroorganizmalar, bazı zararlı maddeler vb. ürünlerin yapı içine nüfuz etmesi, kullanıcı eylemleri ve sağlıksız yapı ürünleri neden olabilmektedir (Balanlı, 2007).

\section{Isıl Konfor}

Isıl konfor, bulundukları ortamda kullanıcıların sıcaklık, nem gibi parametreler açısından duydukları fiziksel ve psikolojik memnuniyet düzeyini ifade etmektedir. Kişilerin ısıl konfor hassasiyetini etkileyen kişisel ve çevresel bazı parametreler bulunmaktadır. Kişisel parametreler; kişinin gerçekleştirdiği eylemler, kıyafet özellikleri, metabolizma hızı gibi parametrelerdir. Çevresel parametreler ise, bulunulan ortamdaki sıcaklık, nem, hava akım hızı gibi değişkenlerdir (Ashrae, 2008). Ortam sıcaklığı, kullanıcıların terleme ya da üşüme olmayacak şekilde ısıl dengelerini sağlayabildikleri takdirde konforlu kabul edilmektedir (Stumpf ve ark., 2001).

Mekan havalandırmasının iç mekandaki kirli hava ile dış mekandaki temiz havanın yer değiştirmesine imkân vermesi gerekmektedir. Hava akım hızı olarak nitelendirilen bu devinim hızı, optimum havalandırma koşullarını sağlaması açısından $0,1 \mathrm{~m} / \mathrm{s}$ 'den az olmamalıdır (Höppe ve Martinac, 1998). Çok yüksek olması durumunda ise kullanıcı konforunu olumsuz yönde etkileyecek esintiler meydana getirmektedir.

Işınım sıcaklığı da konfor koşullarının sağlanması için önemli bir etkiye sahiptir. Ortalama ışınım sıcaklığı, kapalı bir ortamdaki yüzey sıcaklıklarının bireyler üzerindeki etkisini ortaya koyan bir sıcaklık değeridir. Ortamdaki sıcaklık, nem ve havanın devinim hızı yeterli düzeyde olsa da ortalama ışınım sıcaklığından kaynaklanan memnuniyetsizlik durumu oluşabilmektedir. Isıl konforun sağlanması noktasında elverişli bir ortam koşulu için iç yüzey sıcaklıkları ile ortam sıcaklığı arasında bir miktar sıcaklık farkının olması gerekmektedir (Atmaca ve Yiğit, 2005; Zhang ve ark., 2006).

\section{Işitsel Konfor}

Birçok insanın bir arada bulunduğu ortamlarda işitsel konforun gerekliliği daha da önem kazanmaktadır. İşitsel konforun sağlanması için ortamdaki sesin çok alçak ya da gürültü düzeyinde yüksek olmaması gerekmektedir. Ses titreşimlerinin farklı frekans ve yayılma hızına sahip olması, sesin mekanda homojen olarak dağılmaması ve bir takım kişisel faktörler sesin gürültü olarak kabul edilmesini etkileyen parametrelerdir (Yüksel, 2005). Dış mekandan gelen gürültü kadar yapı 
içinde oluşacak gürültüler de kullanıcılarda memnuniyetsizlik oluşturacağından iç mekânda doğru bir akustik tasarım yapılması gerekmektedir. Kullanılan yapı ve donatı malzemelerinin yüksek akustik özellikte olması işitsel konfor açısından fayda sağlamaktadır. İç mekânda işitsel konfor düzeyini arttırabilmek için gürültünün; kaynağında, iletim yolunda ve alıcıda denetim yoluyla azaltılması ya da sönümlendirilmesi sağlanabilmektedir.

\section{Görsel Konfor}

Görsel konfor, kullanıcının rahatsızık duyacağı herhangi bir unsur bulunmadan çevresini yeterli düzeyde algılayabilmesidir. Görsel açıdan net bir şekilde algılanan mekanlar, bireylerde güven duygusu oluşturarak hem psikolojik hem de fiziksel açıdan konfor sağlamaktadır. Görme eyleminin konforlu bir şekilde gerçekleşebilmesi için mekan aydınlatmasının optimum koşulları sağlaması gerekmektedir. İç mekanlarda aydınIığın şiddeti, karakteri, ışığın rengi, gölge, kamaşma gibi faktörler 'genel konfor etkisi' olarak adlandırılmaktadır (Alkan, 2010). Bu faktörler doğru ve etkin bir şekilde kullanıldığında görsel konfor koşullarını olumlu yönde geliştirmektedir.

Görsel algının etkin bir biçimde gerçekleşmesi için mekandaki renklerin, biçimlerin ve yüzeylerin dokusal özelliklerinin de algılanması gerekmektedir (Sözen, 2014). Dolayısıyla doğal ve yapay aydınlatma kadar yüzeylerin renk, şekil ve dokusu da görsel konforu destekleyen parametreler arasındadır. Bu parametreler bireyler üzerinde farklı psikolojik etkilere sahiptir. Kullanımı farklılaşan renk, şekil ve dokularla mekânın görsel algısı değiştirilebilmektedir.

\section{Sürdürülebilir Eğitim Yapıları}

Eğitim yapılarında hem yapım hem de yapı kullanım aşamasında önemli oranda kaynak tüketimi söz konusudur. Okullardaki yüksek enerji tüketimi genellikle düşük çevre kalitesi, yalıtımsız kapı ve pencereler, Isı köprüleri, eski ekipmanlar vb. nedenlerden kaynaklanmaktadır (Boeri and Longo, 2013). Bu bağlamda eğitim yapılarının çevre üzerinde büyük bir etkisi bulunmaktadır. Ayrıca eğitim ortamlarının sahip olduğu fiziksel koşullar eğitmenlerin öğretme, öğrencilerin ise öğrenme potansiyellerine katkı sağlamaktadır. Dolayısıyla etkin bir öğrenme ortamı, eğitimin teşvik edilmesi ve desteklenmesi noktasında önemli bir paya sahiptir (Hes, 2009). Bu noktada eğitim yapılarının öğretmenlerin ve öğrencilerin performanslarını iyileştirmeye yönelik sunduğu katkılar ayrıca bir araştırma konusu olup farklı çalışmalarda ele alınması mümkündür.
Ford (2007), hayatımız üzerinde en etkili yapı grubunun eğitim yapıları olduğunu savunmaktadır. Özellikle temel eğitim döneminde beyin gelişimini etkileyen çevresel birçok unsur bulunmaktadır. Bu noktada eğitim yapılarının sahip olduğu fiziksel koşulların öğrenme deneyimimiz üzerinde tüm hayatımıza yayılan önemli bir etkisi bulunmaktadır. Sürdürülebilir bir okul, öğrencilere sunduğu nitelikli bir fiziksel çevrenin yanı sıra uyguladığı eğitim programıyla da sürdürülebilirliğin bir yaşam felsefesi olarak hayata dahil edilmesini sağlamaktadır. Sürdürülebilir okul binaları için tasarım aşamasından üretim ve kullanım aşamasına kadar binanın tüm yaşam döngüsünü kapsayan bütüncül bir tasarım yaklaşımının benimsenmesi gerekmektedir. Öğrenciler kadar bulunduğu çevre halkını da etkileyen sürdürülebilir okullar, yapım ve kullanım aşamasındaki giderleri ve ekosistem üzerindeki etkiyi azaltması, enerji ve kaynak tasarrufu sağlaması, yerel tüketimi desteklemesi, verimli ve kaliteli iç mekanlar sunması, kullanıcıların konfor ve memnuniyetini arttırarak performanslarını iyileştirmesi gibi konularda önemli katkılar sunmaktadır (Olson and Kellum, 2003; Gökmen, 2012; Karadayı ve ark., 2017; Tonguç ve Özbayraktar, 2017).

Tüm yapı gruplarında olduğu gibi eğitim yapılarında da birtakım sürdürülebilirlik kriterlerinin uygulanması gerekmektedir. Gün ışığının etkin kullanımı, ısıtma-soğutma ve havalandırmanın pasif yöntemlerle sağlanması, yapı kabuğunda ve iç mekânda sağlıklı malzemelerin seçimi, yeterli akustik performans, etkin enerji kullanımı, su tüketiminin azaltılması, yapı tasarımının doğanın bir parçası olarak ele alınması gibi kriterler konforlu ve etkili bir öğrenme ortamı oluşturulmasını sağlamaktadır.

\section{MATERYAL VE YÖNTEM}

Türkiye genelinde LEED sertifikalı temel eğitim okullarının en yoğun olarak bulunduğu il olması nedeniyle alan çalışması için İstanbul ili tercih edilmiştir. İstanbul'daki devlet okulları arasında LEED sertifikasına sahip temel eğitim okulu bulunmazken 3 adet LEED sertifikalı özel okul olduğu tespit edilmiştir. Tespit edilen bu okullar; Bahçeşehir Cihangir Koleji, Ted Rönesans Koleji ve Tuzla Terakki Vakfı Okulu'dur. Okulların özel okul statüsünde olması nedeniyle alan çalışması için Milli Eğitim Bakanlığı'nın yanı sıra okul yönetim kurullarının da onay vermesi gerekmektedir. Bu bağlamda okul yönetim kurulunun gerekli izni vermemesinden dolayı TED Rönesans Koleji çalışmaya dahil edilmeyerek Cihangir Koleji ve Terakki Vakfı Okulu çalışma alanı olarak belirlenmiştir. Çalışmanın ilerleyen kısımlarında kolay ifade edilmesi açısından Cihangir Koleji 
A okulu, Terakki Vakfı Okulu ise B okulu olarak kodlanmıştır.

Anaokulu, ilkokul, ortaokul ve lise düzeylerinde eğitim veren Bahçeşehir Cihangir Koleji (A Okulu), 2014-15 eğitim öğretim yılında faaliyete geçmiştir (Şekil 1). Açık alanlarla birlikte toplam $16.500 \mathrm{~m}^{2}$ arsa alanı üzerinde yer almaktadır. Toplamda 864 öğrencisi bulunmaktadır. 2015 yılında 'Certified' dereceli LEED sertifikası almaya hak kazanmıştır.

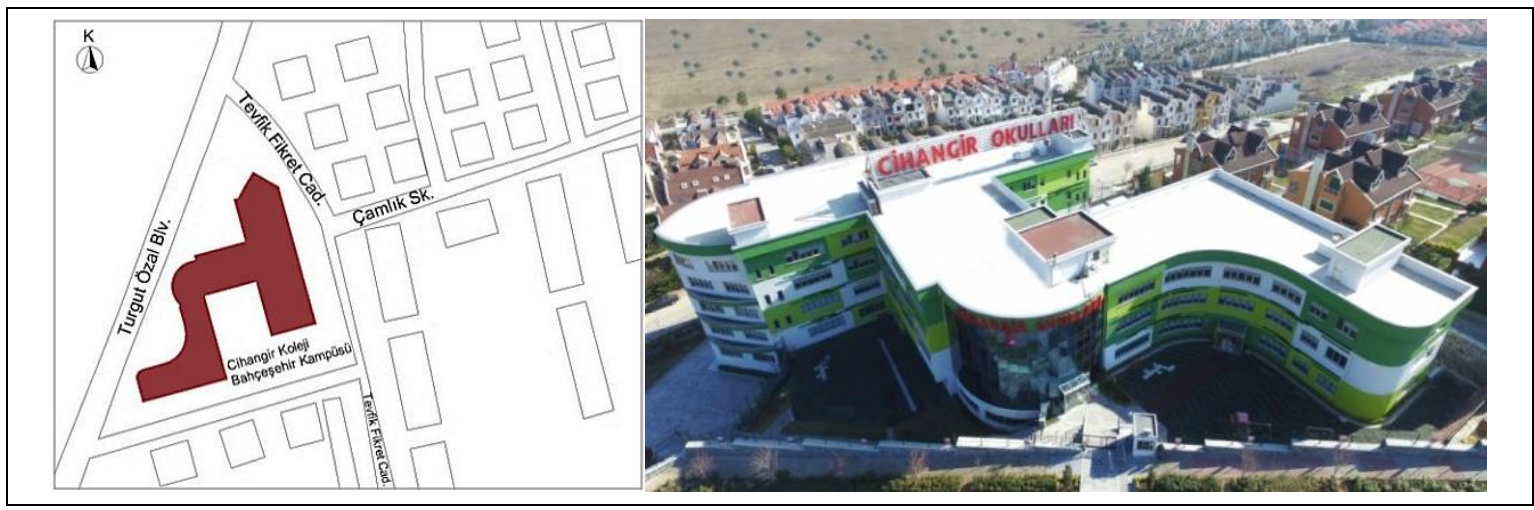

Şekil 1. Cihangir Koleji (A Okulu), Bahçeşehir Kampüsü (URL-2, 2020)

Okul bünyesinde açık kapalı spor alanları, yüzme havuzu, görsel sanatlar atölyesi, müzik atölyesi, satranç atölyesi, yaratıcı drama atölyesi, sinema salonu ve konferans salonu gibi sosyal mekânlar yer almaktadır. Aynı zamanda okul bahçesinde bulunan ekolojik tarım alanı çocukların ekip biçme aktiviteleri yapmalarına imkân vermektedir. Okul bünyesinde dersliklerin boyutları $7,7 \times 6,25 \mathrm{~m}$, yüksekliği ise $3,35 \mathrm{~m}$ olup $48 \mathrm{~m}^{2}$ lik bir alana sahiptir.

Alan çalışması yapılan bir diğer okul Terakki Vakfı Okulları'nın (B Okulu) TuzlalTepeören kampüsüdür (Şekil 2).
Okul projesi, 2008 yılında Terakki Vakfı tarafından açılan mimari proje yarışmasında birincilik ödülü almış ve 2013 yılında kampüs inşaatına başlanmıştır. Kampüs açılışı Eylül 2014'te gerçekleşmiştir. Toplamda 68.166 $\mathrm{m}^{2}$ arsa alanına sahip yerleşkede; anaokulu, ilkokul, ortaokul ve lise birimleri yanında çok amaçlı 650 kişilik büyük bir kültür merkezi de yer almaktadır. Toplamda 870 öğrencisi bulunmaktadır. 2018 yılında LEED 'Gold' sertifikası almıştır.
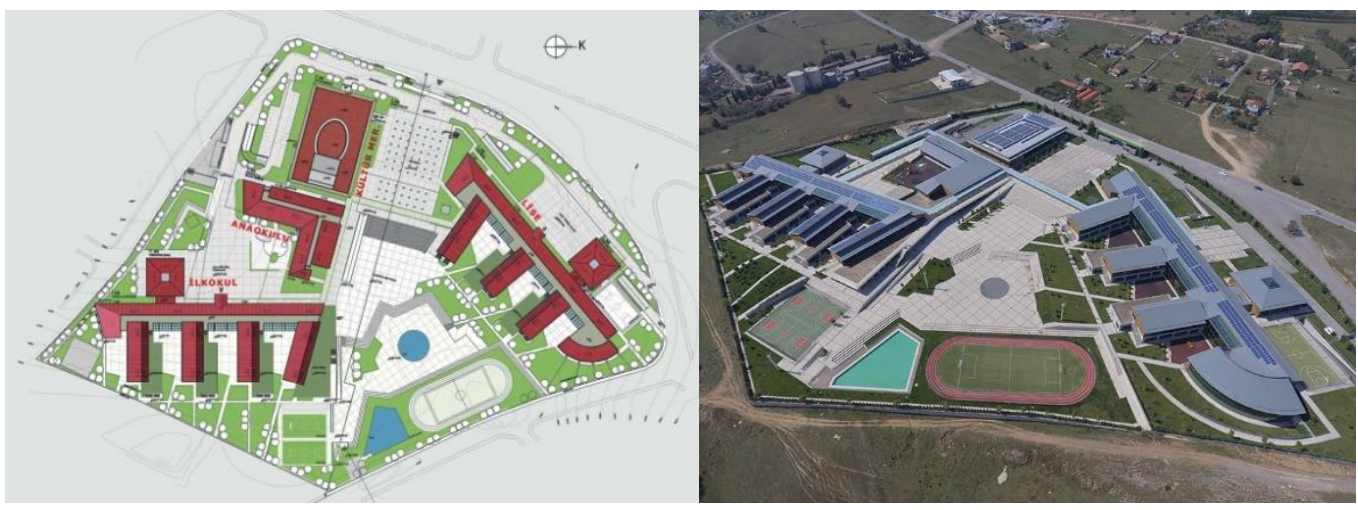

Şekil 2. Terakki Vakfı Okulları (B Okulu), Tuzla\Tepeören Kampüsü (URL-3, 2020)

Terakki Vakfı Okulu'nda (B Okulu) konferans salonu, açık ve kapalı spor alanları, yüzme havuzu, öğrenci kulüpleri, kütüphane ve ekolojik tarım alanı gibi açık ve kapalı mekân aktiviteleri yer almaktadır. Okul bünyesindeki dersliklerin boyutları $7,9 \times 8 \mathrm{~m}$, yüksekliği ise $3,4 \mathrm{~m}$ olup $63 \mathrm{~m}^{2}$ lik bir alana sahiptir.

Alan çalışması yapılan okullarda kullanıcıların iç mekan konforuna ilişkin görüşlerini tespit edebilmek amacıyla 
anket uygulaması yapılmıştır. Öğretmen ve öğrenciler olmak üzere iki farklı kullanıcı grubuna hazırlanan anketler, LEED sertifikasının iç ortam kalitesini arttırmaya yönelik önerdiği kriterler çerçevesinde oluşturulmuştur.
LEED sertifikasının “iç mekan kalitesi” başlığı altında geliştirdiği kriterler ve okulların bu kriterlerden aldığı puanlar Tablo 1'de gösterilmiştir.

Tablo 1. Okullara ait iç mekan kalitesi kredi puanları

\begin{tabular}{|c|c|c|c|}
\hline Kredi & İç Mekan Kalitesi & $\begin{array}{c}\text { A Okulu } \\
\text { Puanı }\end{array}$ & $\begin{array}{c}\text { B Okulu } \\
\text { Puanı }\end{array}$ \\
\hline Önkoșul 1 & Minimum İç Hava Kalitesi Performansı & Gerekli & Gerekli \\
\hline Önkoșul 2 & Çevresel Sigara Dumanı Kontrolü & Gerekli & Gerekli \\
\hline Önkoșul 3 & Minimum Akustik Performans & Gerekli & Gerekli \\
\hline Kredi 1 & Dıș Hava Dağıtımı İzleme & $0 / 1$ & $0 / 1$ \\
\hline Kredi 10 & Küf Önleme & $0 / \mathbf{1}$ & $0 / \mathbf{1}$ \\
\hline Kredi 2 & Arttırılmıș Havalandırma & $0 / \mathbf{1}$ & $0 / \mathbf{1}$ \\
\hline Kredi 3.1 & İnşaat Sırasında İç Mekan Hava Kalitesi Yönetim Planı & $1 / \mathbf{1}$ & $1 / \mathbf{1}$ \\
\hline Kredi 3.2 & Oturumdan Önce İç Mekan Hava Kalitesi Yönetim Planı & $0 / 1$ & $0 / 1$ \\
\hline Kredi 4 & Düșük Salınımlı Malzemeler & $1 / 4$ & $1 / 4$ \\
\hline Kredi 5 & İç Mekan Kimyasal ve Kirletici Madde Kontrolü & $1 / 1$ & $1 / 1$ \\
\hline Kredi 6.1 & Sistemlerin Denetlenebilirliği-Işıklandırma & $1 / \mathbf{1}$ & $0 / \mathbf{1}$ \\
\hline Kredi 6.2 & Sistemlerin Denetlenebilirliği-Sıcaklık Konforu & $1 / 1$ & $1 / 1$ \\
\hline Kredi 7.1 & Sicaklık Konforu-Tasarım & $0 / 1$ & $0 / \mathbf{1}$ \\
\hline Kredi 7.2 & Sicaklık Konforu-Doğrulama & $0 / \mathbf{1}$ & $0 / \mathbf{1}$ \\
\hline Kredi 8.1 & Gün Iș1 $\check{g ̆}_{1}$ ve Manzara-Gün Iș1ğ 1 & $1 / 3$ & $0 / \mathbf{3}$ \\
\hline Kredi 8.2 & Gün Ișığ 1 ve Manzara-Manzara & $1 / \mathbf{1}$ & $0 / \mathbf{1}$ \\
\hline Kredi 9 & Gelişmiş Akustik Performans & $0 / \mathbf{1}$ & $0 / \mathbf{1}$ \\
\hline \multicolumn{2}{|c|}{$\begin{array}{ll} & \text { Toplam Puan }\end{array}$} & $7 / 19$ & $4 / 19$ \\
\hline
\end{tabular}

Anket sorularının en kısa sürede cevaplanabilmesi ve özellikle ilkokul çağındaki öğrenciler için kolay algılanır olması açısından kapalı uçlu sorular hazırlanmıştır. Anket çalışmasına, okullarda görev yapan tüm öğretmenler ve ilkokul 4. sınıf ile ortaokul 7. sınıf öğrencilerinin tamamı dahil edilmiştir. İlkokullarda 4. Sınıf öğrencilerinin alt sınıf gruplarına göre fiziksel çevreyi algılama ve yorumlama noktasında daha bilinçli olması, ortaokullarda ise 8. Sınıf öğrencilerinin ders yoğunluğu nedeniyle bir alt yaş grubu olarak 7 . Sınıfların tercih edilmesi örneklem grubunun seçim kriterleri arasındadır. Bu bağlamda ankete katılan örneklem sayısı Tablo 2'de gösterilmiştir.

Tablo 2. Anket uygulanan örneklem sayısı

\begin{tabular}{|c|c|c|c|c|}
\hline \multirow{2}{*}{ OKULLAR } & \multicolumn{2}{|c|}{ Öğrenci Sayısı } & \multirow{2}{*}{$\begin{array}{c}\text { Öğretmen } \\
\text { Sayısı }\end{array}$} & \multirow{2}{*}{ Toplam Örneklem Sayıs } \\
\hline & 4. SinIf & 7. Sinif & & \\
\hline A Okulu & 42 & 28 & 20 & 90 \\
\hline B Okulu & 37 & 17 & 27 & 81 \\
\hline Toplam & 79 & 45 & 47 & 171 \\
\hline
\end{tabular}

Kullanıcıların okullarda en çok zaman geçirdikleri mekânların derslikler olması nedeniyle anketlerde örneklem grubunun derslik mekânlarına ilişkin görüşlerine ağırlık verilmiştir. Anket soruları incelenen okulların; iç hava kalitesi, ısıl konfor, işitsel konfor ve görsel konfora dair koşullarını sorgulamaktadır. Bu başlıklar altında örneklem grubuna yöneltilen sorular Şekil 3'te verilmiştir. 


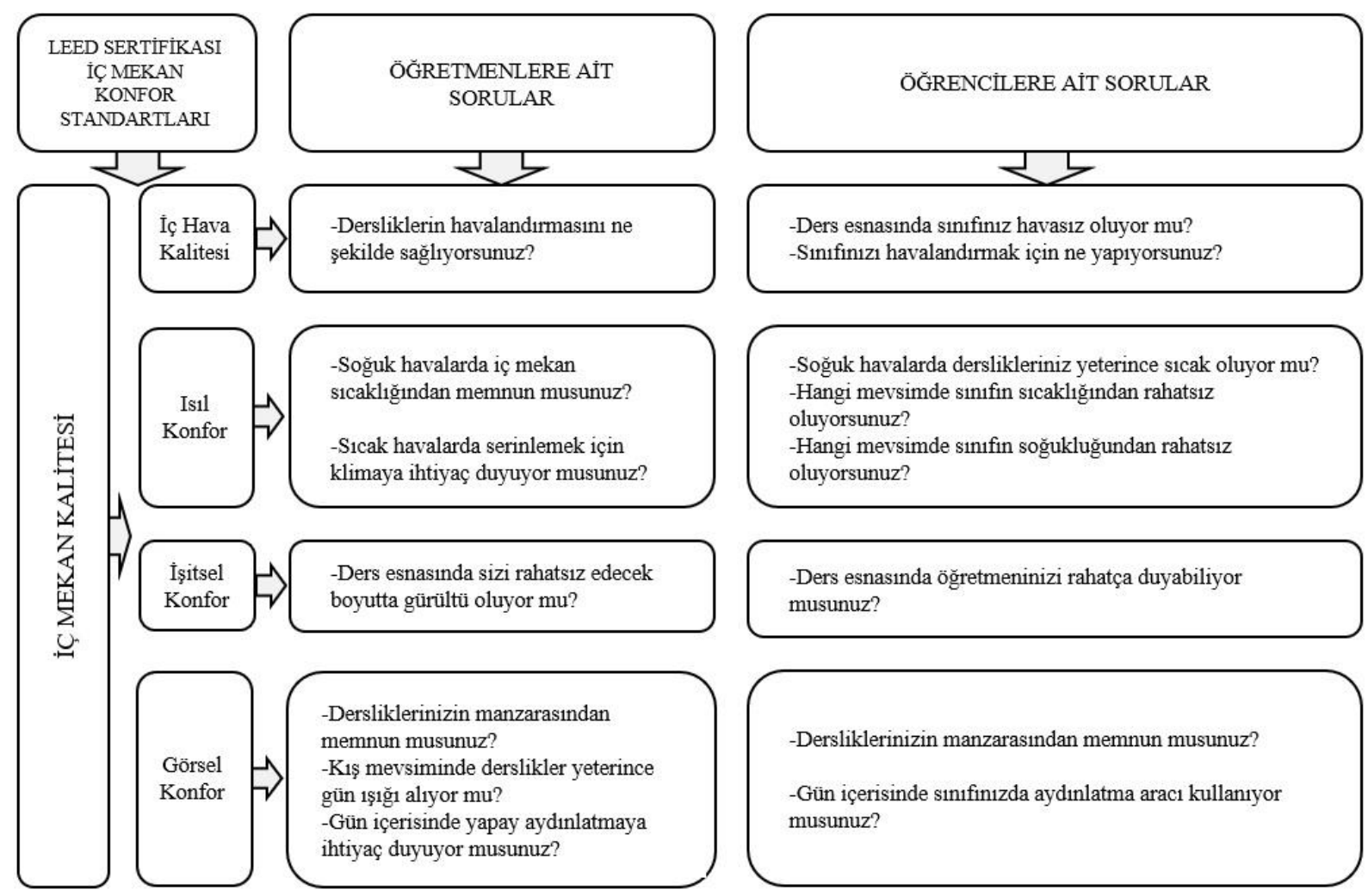

Şekil 3. Örneklem grubuna yöneltilen sorular

Anketlerden elde edilen verilere SPSS 22 programı ile frekans ve ki-kare analizleri uygulanmıştır.

\section{BULGULAR VE TARTIŞMA}

Anketlerde fiziksel konfor koşullarına ilişkin sorulara verilen yanıtlar frekans dağııım grafikleri ile gösterilmiştir. Ankete katılan öğrencilerin \%52,4'ü kız, \%47,6'sı erkek öğrencilerden oluşmaktadır. Öğretmenlerin ise \%55,3'ü kadın, \%44,7'si erkektir.

\section{İç Hava Kalitesi}

Dersliklerin hava kalitesine ilişkin memnuniyet düzeyini ölçmek için yöneltilen soruya öğrencilerin verdikleri cevaplar Şekil 4'te belirtilmiştir. Dersliklerin havalandırma yöntemine ilişkin soruya ise öğretmenlerin tamamı duvar pencereleri aracılığıyla pasif havalandırma yaptıklarını ifade etmiştir.

'Sınıfınızı havalandırmak için ne yapıyorsunuz?' sorusuna \%58,9'luk oranla öğrencilerin büyük çoğunluğu pencereleri ve kapıları açıyoruz yanıtını vermiştir (Şekil $5)$.

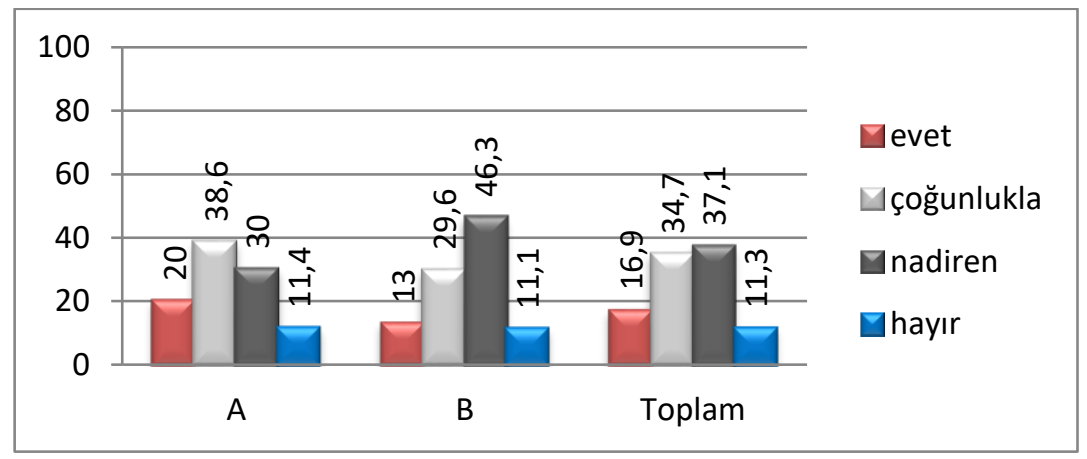

Şekil 4. 'Ders esnasında sınıfınız havasız oluyor mu?' sorusuna verilen cevapların grafiği 


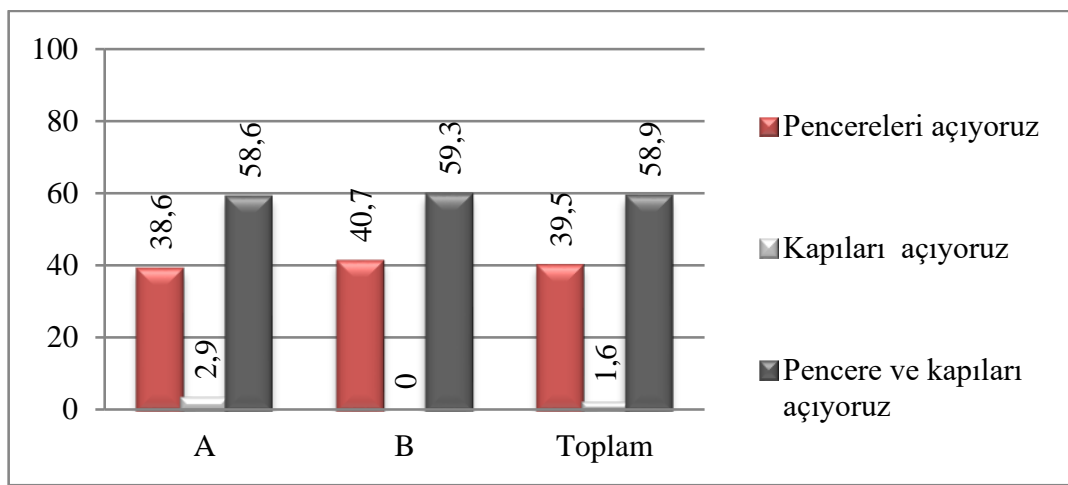

Şekil 5. 'Sınıfınızı havalandırmak için ne yapıyorsunuz?' sorusuna verilen cevapların grafiği

A ve $B$ okulu öğrencilerinin iç hava kalitesine dair görüşleri incelendiğinde; A okulu öğrencileri 'çoğunlukla', B okulu öğrencileri ise 'nadiren' dersliklerinin havasız olduğunu ifade etmiştir. İç hava kalitesi açısından her iki okulun derslik boyutları ideal ölçülerde olmasına rağmen A okulu öğrencilerinin memnuniyetsizliğinin, kişi başına düşen hacim miktarıyla ilgili olduğu düşünülmektedir. A okulunda dersliklerin kişi başı hacim miktarı 6,7 $\mathrm{m}^{3}$ iken B okulunda bu hacmin $8,7 \mathrm{~m}^{3}$ olduğu tespit edilmiştir. Dolayısıyla B okulu dersliklerinin iç hava kalitesi konfor düzeyinin A okulu dersliklerine göre daha yüksek olduğu söylenebilir. Öte yandan okulların LEED sertifikası puan kartları incelendiğinde; her iki okulun da iç hava kalitesi açısından gerekli önkoşulları sağladığı fakat küf önleme, arttırımış havalandırma ve oturumdan önce iç mekân hava kalitesi yönetim planı kredilerinden puan alamadığı görülmüştür.
Her iki okulda öğrenciler, derslikleri pencere ve kapıları açarak havalandırdıklarını belirtmiştir. Buna paralel olarak ankete katılan öğretmenlerin tamamı da pencereler vasıtasıyla pasif havalandırma yaptıklarını ifade etmiştir. Bu bağlamda sürdürülebilir eğitim yapılarında enerji verimliliği açısından önerilen pasif havalandırma yöntemlerinin her iki okulda da uygulandığı tespit edilmiştir.

\section{Isıl Konfor}

Soğuk havalarda dersliklerin sıcaklık düzeyinin yeterli olup olmadığına ilişkin soruya karşılık öğrencilerin $\% 67,7$ 'si yeterince sıcak olduğunu belirtmiştir. A okulundaki öğrencilerin \%64,3'ü, B okulundaki öğrencilerin ise $\% 72,2$ 'si olmak üzere büyük çoğunluğu dersliklerin ısı düzeyinden memnun olduğunu ifade etmiştir (Şekil 6).

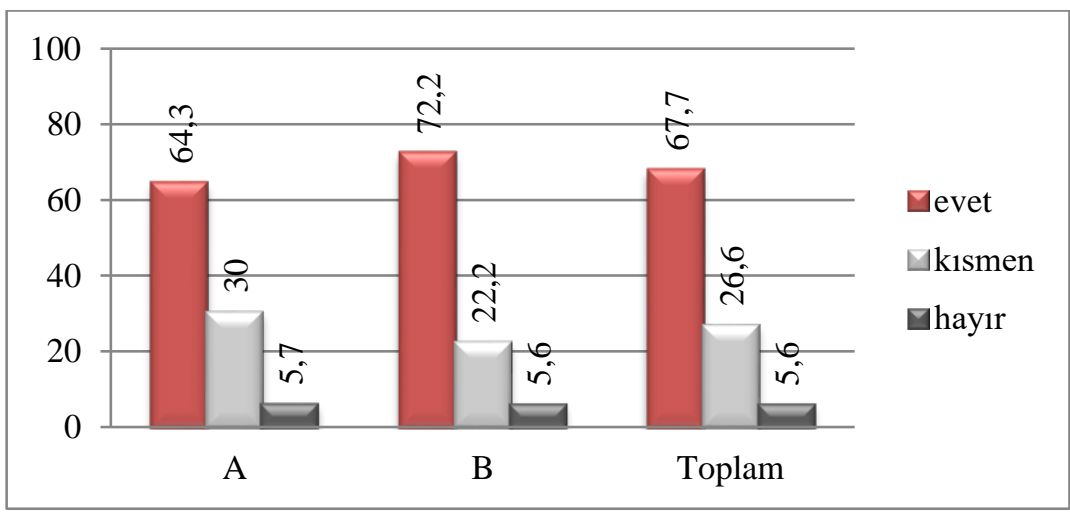

Şekil 6. 'Soğuk havalarda derslikleriniz yeterince sıcak oluyor mu?' sorusuna verilen cevapların grafiği

Ankete katılan öğrencilerin çoğunluğu $(\% 54,8)$ sınıfların sıcaklığından hiçbir mevsimde rahatsızlık duymadıklarını belirtmiştir. Öte yandan A okulundaki öğrencilerin $\% 30$ 'u, B okulundaki öğrencilerin ise \%31,5'i ilkbahar mevsiminde sınıfların sıcaklığından memnun olmadıklarına ilişkin görüş bildirmiştir (Şekil 7).
Benzer şekilde sınıfların soğukluğundan rahatsızlık duyup duymadıklarına karşılık öğrencilerin çoğu $(\% 48,4)$ hiçbir mevsimde rahatsız olmadığını ifade ederken $\% 45,2$ 'si ise kış mevsiminde sınıfların soğuk olduğuna ilişkin görüş bildirmiş̧tir (Şekil 8). 


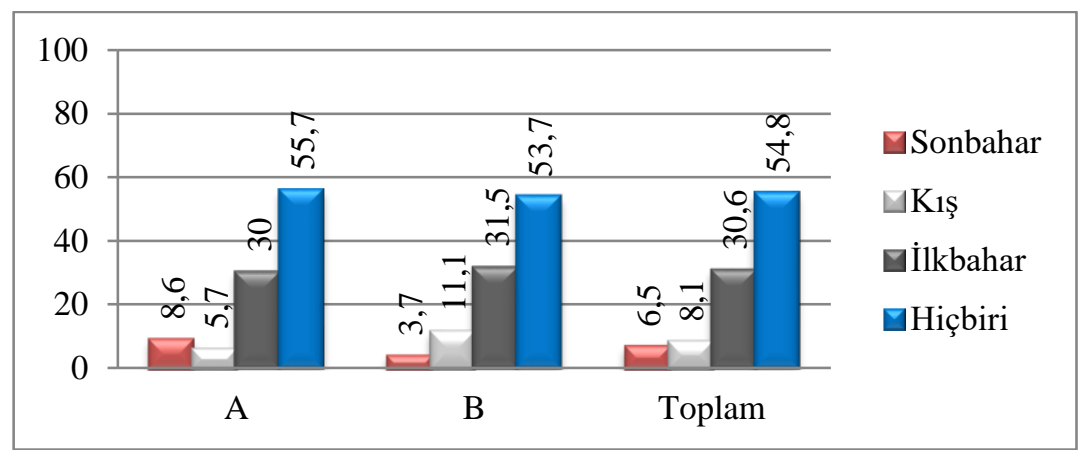

Şekil 7. 'Hangi mevsimde sınıfın sıcaklığından rahatsız oluyorsunuz?' sorusuna verilen cevapların grafiği

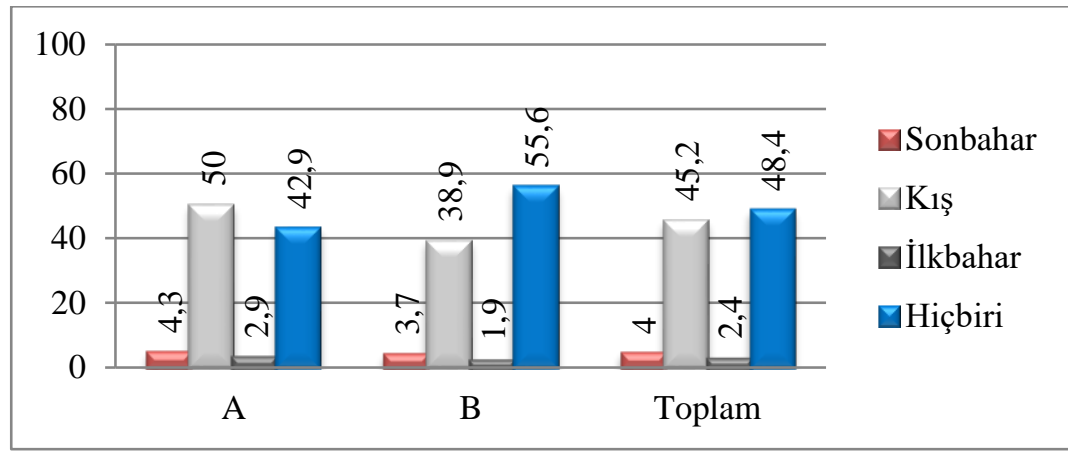

Şekil 8. 'Hangi mevsimde sınıfın soğukluğundan rahatsız oluyorsunuz?' sorusuna verilen cevapların grafiği

Ankete katılan öğretmenlerin tamamına yakını $(\% 91,5)$ soğuk havalarda iç mekan sıcaklığından memnun olduklarını belirtmiştir (Şekil 9).
Anket verilerine göre öğretmenlerin \%55'i, sıcak havalarda serinlemek için klimaya intiyaç duyarken \%14,9'u ise intiyaç duymamaktadır (Şekil 10).

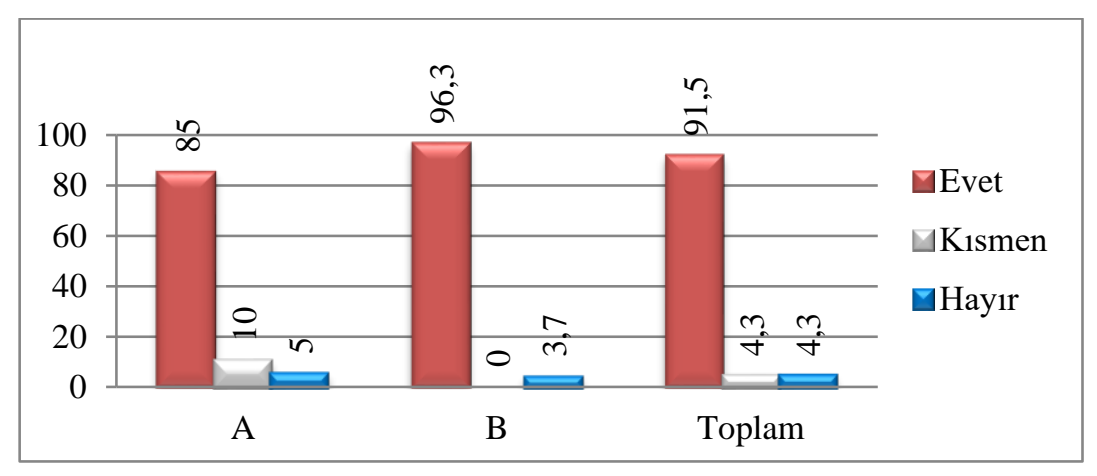

Şekil 9. 'Soğuk havalarda iç mekân sıcaklığı sizi memnun ediyor mu?' sorusuna verilen cevapların grafiği 


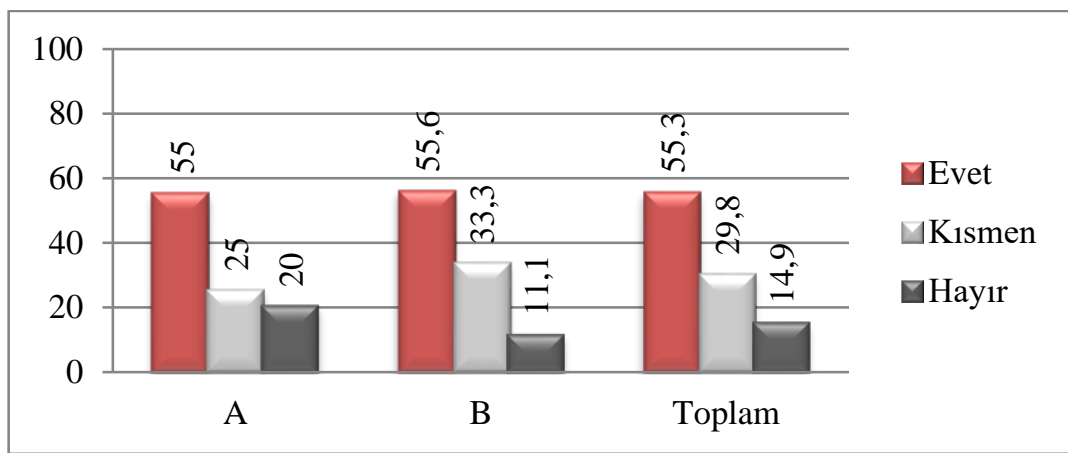

Şekil 10. 'Sıcak havalarda serinlemek için klimaya ihtiyaç duyuyor musunuz?' sorusuna verilen cevapların grafiği

Isıl konfora ilişkin kullanıcı görüşleri incelendiğinde; öğrencilerin büyük çoğunluğu dersliklerin soğuk havalardaki sıcaklık düzeyinden memnun olduğunu belirtmiştir. Öte yandan A okulundaki öğrencilerin \%50'si, B okulundaki öğrencilerin ise \%38,9'u sınıfların kış mevsiminde soğuk olduğu yönünde görüş bildirmiştir. Bu bağlamda $B$ okulu dersliklerinin güney yönünde konumlandırılmış olmasının ısıl konfor açısından kullanıcı memnuniyetini arttırdığı görülmektedir.

Cinsiyetin, öğrencilerin ısıl konfora ilişkin görüşleri üzerinde bir farklılık yaratıp yaratmadığını belirlemeye yönelik ki-kare analizi yapılmıştır. Bu analiz sonucuna göre, soğuk havalarda dersliklerin sıcaklığından memnun olup olmama durumu cinsiyete göre anlamlı bir farklılık oluşturmamaktadır $(P=, 191)$. Benzer şekilde hangi mevsimde sınıf soğukluğundan rahatsız olunduğuna ilişkin soruya verilen cevaplarda da cinsiyete bağlı bir farklılık görülmemektedir ( $P=, 875)$. Öte yandan hangi mevsimde sınıf sıcaklığından rahatsızlık duyulduğuna ilişkin kullanıcı görüşleri cinsiyete göre anlamlı bir değişkenlik göstermektedir $(P=, 023)$. Bu bağlamda erkek öğrencilerin $\% 7,3$ 'ü, kız öğrencilerin ise \%0,8'i kış mevsiminde sınıfların sıcaklığından rahatsızlık duyduğunu belirtmiştir.

A ve B okulunda ankete katılan öğretmenlerin neredeyse tamamı soğuk havalardaki iç mekân sıcaklığını yeterli bulduklarını belirtmiştir. Sıcak havalarda ise öğretmenlerin çoğu serinlemek için klimaya intiyaç duyduklarını ifade etmiştir. Sıcak havalarda kullanıcılarda serinlik hissi uyandıran havalandırma, konfor havalandırması olarak tanımlanmaktadır. Konfor havalandırmasının etkin bir serinlik sağlaması için mekandaki açılır havalandırma boşluklarının alanı, toplam taban alanının yaklaşık \%20'si kadar olmalıdır. Bu bakımdan A ve B okulu dersliklerinin açılabilir kapı ve pencere boşluklarının konfor havalandırması için yetersiz kaldığı söylenebilir. Ayrıca A okulu dersliklerinin doğu ve batı yönünde konumlandı- rılmış olması, derslikleri günün yarısında doğrudan güneş ışığına maruz bırakmaktadır. Dolayısıyla yoğun güneş ışığı alan dersliklerde ortam sıcaklığı artmakta ve konfor havalandırmasının etkinliği azalmaktadır.

Dersliklerin sıcaklık düzeyinden duyulan memnuniyetin cinsiyete göre değişkenlik gösterip göstermediğini tespit etmek amacıyla yapılan ki-kare analizinin sonucuna göre öğretmenlerin ısıl konfora ilişkin görüşleri cinsiyete bağlı bir farklılık göstermemektedir $(P=, 439)$. Aynı zamanda sıcak havalarda klimaya duyulan ihtiyacın sorgulanması noktasında da cinsiyete bağlı bir farlılık bulunmamaktadır $(\mathrm{P}=, 667)$.

LEED sertifikası kriterlerinden biri olan termal konforun sağlanmasına yönelik ısıtma-soğutma ve havalandırma sistemlerinin kontrol edilebilirliği kriteri her iki okul için de sağlanmıştır. Buna karşılık ısıl konfor için gerekli görülen ısıtma-havalandırma ve klima sistemlerini gerekli kılan 'termal konfor-tasarım' ve bina kullanım aşamasında kullanıcılara yönelik bir memnuniyet anketi yapılmasını öneren 'termal konfor-doğrulama' kriterlerinden puan alamadıkları görülmüştür.

\section{İşitsel Konfor}

Öğrencilerin \%54,8'lik kısmı ders esnasında öğretmenlerini rahatlıkla duyabildiklerini belirtmiştir. Dışarıdan gelen gürültüye karşılık öğrencilerin konfor düzeyi her iki okul için incelendiğinde; A okulu öğrencilerinin \%30'u, B okulu öğrencilerinin ise $\% 20,4$ 'ü dışarıdan gürültü gelmediği zamanlarda duyabildiğini ifade etmiştir (Şekil 11).

Öğretmenlerin işitsel konfora ilişkin görüşleri çoğunlukla $(\% 57,4)$ ders esnasında gürültü olmadığı yönündedir. Öte yandan öğretmenlerin \%40,4'ü de diğer mekanlardan ya da dışarıdan gürültü geldiği yönünde görüş bildirmiştir (Şekil 12). 


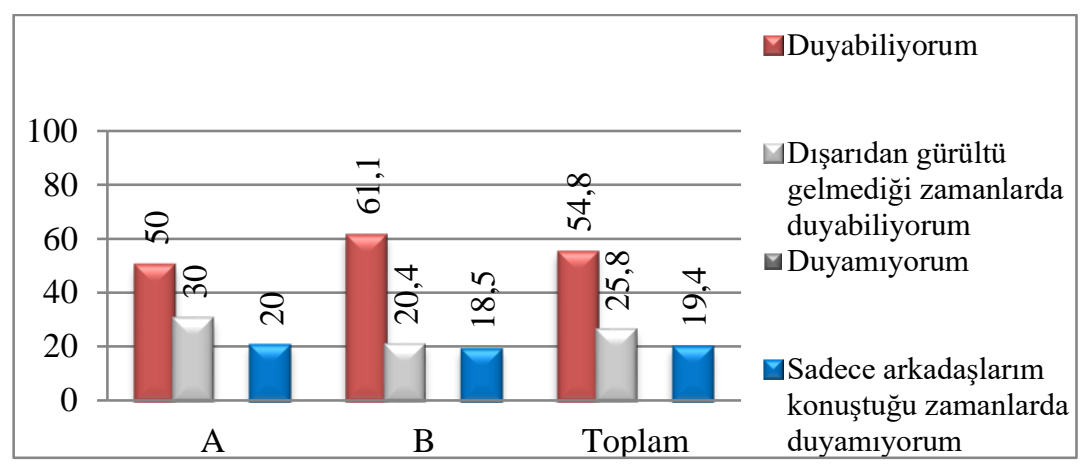

Şekil 11. 'Ders esnasında öğretmeninizi rahatça duyabiliyor musunuz?' sorusuna verilen cevapların grafiği

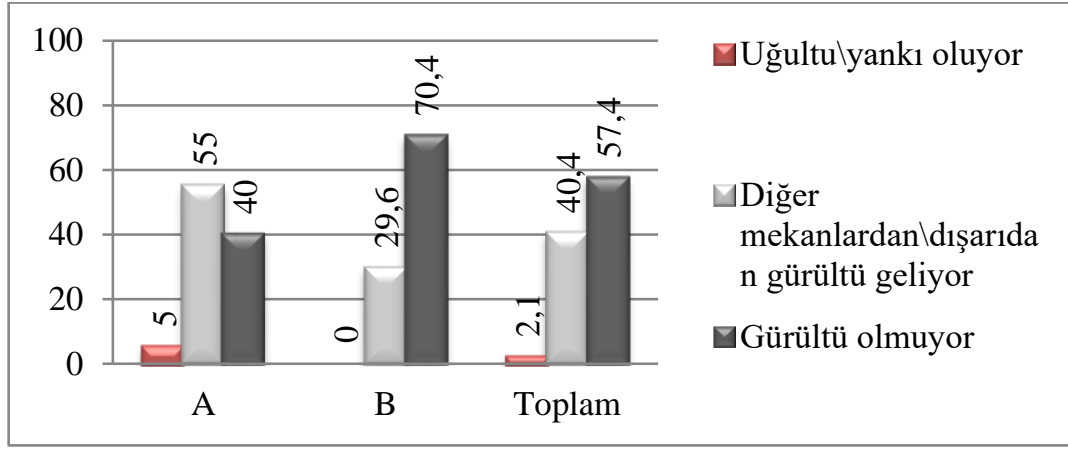

Şekil 12. 'Ders esnasında sizi rahatsız edecek boyutta gürültü oluyor mu?' sorusuna verilen cevapların grafiği

Genel olarak A ve B okulu öğrencilerinin işitsel konfora ilişkin görüşleri ders esnasında öğretmenlerini rahatlıkla duyabildikleri yönündedir. A okulu bulunduğu konum itibariyle az yoğunluklu bir konut bölgesinde yer alırken B okulu kampüsü de yapılaşmanın olmadığı bir kırsalda yer almaktadır. Aynı zamanda B okulu dersliklerinde akustik tavan panelleri kullanılarak iç mekanda oluşacak gürültü düzeyini azaltmaya yönelik birtakım önlemler alınmıştır. Genel bir değerlendirme yapıldığında okulların şehir merkezinden uzakta olmasının işitsel konfor açısından öğrencilerin memnuniyet düzeylerini arttırdığı görülmektedir.

Ankete katılan öğretmenlerin işitsel konfora dair memnuniyet düzeyleri sorgulandığında; A okulu öğretmenlerinin \%55'i, B okulu öğretmenlerinin ise \%29,6'sı dışarıdan ya da bina içerisindeki diğer mekanlardan gelen gürültüden rahatsızlık duyduğunu ifade etmiştir. İki okuldaki öğretmenler arasında ortaya çıkan bu görüş farklılığının, istatistiki anlamda geçerli bir fark olup olmadığı bakılmaksızın dersliklerin konumlandırılması ile yakından ilişkili olduğu düşünülmektedir. A okulunda derslikler bir koridor boyunca karşılıklı olarak sıralanmakta ve çok katlı bina yapısı nedeniyle alt ve üst katlardan da başka mekanlarla çevrelenmektedir. B okulunda ise derslikler yapının bir cephesinde yer alırken diğer cepheden ortak bir avluya çıkılmaktadır. Bununla birlikte okul binasının 2 katı olması dersliklerin çevrelendiği mekan sayısını azaltmakta ve dolayısıyla diğer mekanlardan gelebilecek gürültü düzeyini en aza indirmektedir.

LEED sertifikasının ön koşul olarak belirlediği minimum akustik performans kriteri her iki okul için de sağlanmış olup gelişmiş akustik performansa yönelik gerekli puanı alamadıkları belirlenmiştir.

\section{Görsel Konfor}

\section{'Manzara'}

'Dersliklerinizin manzarasından memnun musunuz?' sorusuna öğrencilerin \%61,3'ü memnun olduğunu belirtmiştir. Aynı soruya karşılık öğretmenlerin ise \%66'sı memnun olduğunu yanıtını vermiştir (Şekil 13). 


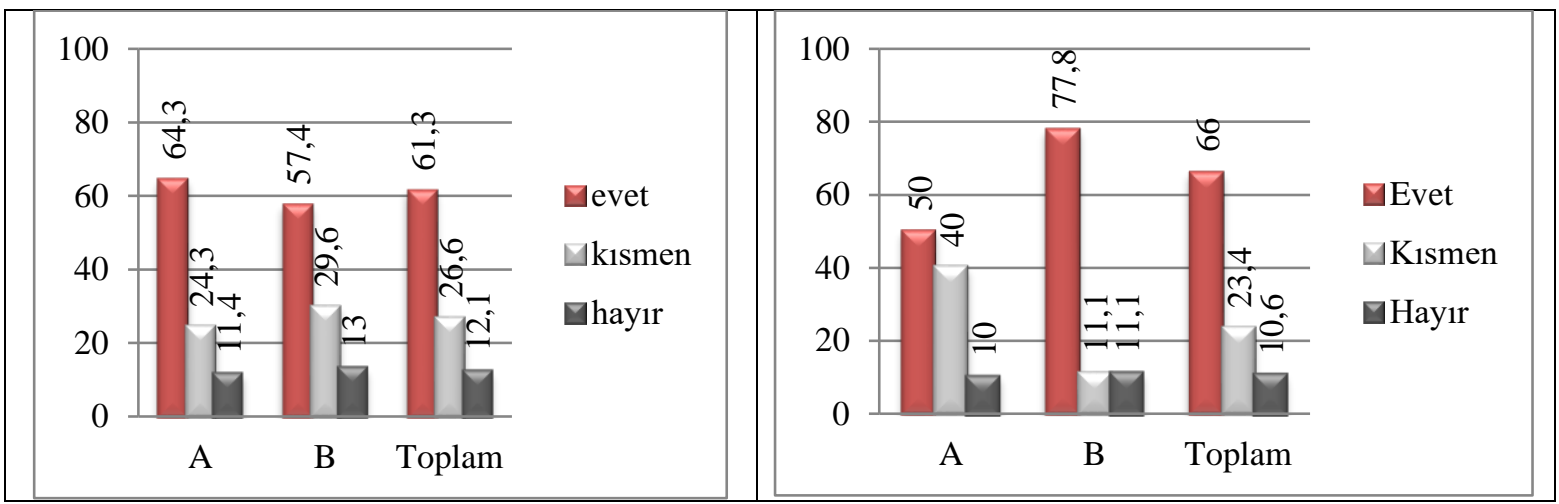

Şekil 13. Dersliklerin manzarasından memnuniyet durumu grafiği

'Gün ışığı kullanımı'

'Gün içerisinde sınıfınızda aydınlatma aracı kullanıyor musunuz?' sorusuna öğrencilerin $\% 68,5$ 'i güneşli olmayan günlerde kullandıkların belirtmiştir (Şekil 14).
Gün içerisinde yapay aydınlatma intiyacına karşılık öğretmenlerin \%61,7'si kısmen ihtiyaç duyduğunu belirtmiştir. Bu oran A okulu öğretmenlerinde \%15 iken B okulu öğretmenlerinde \%3,7'ye düşmektedir (Şekil 15).

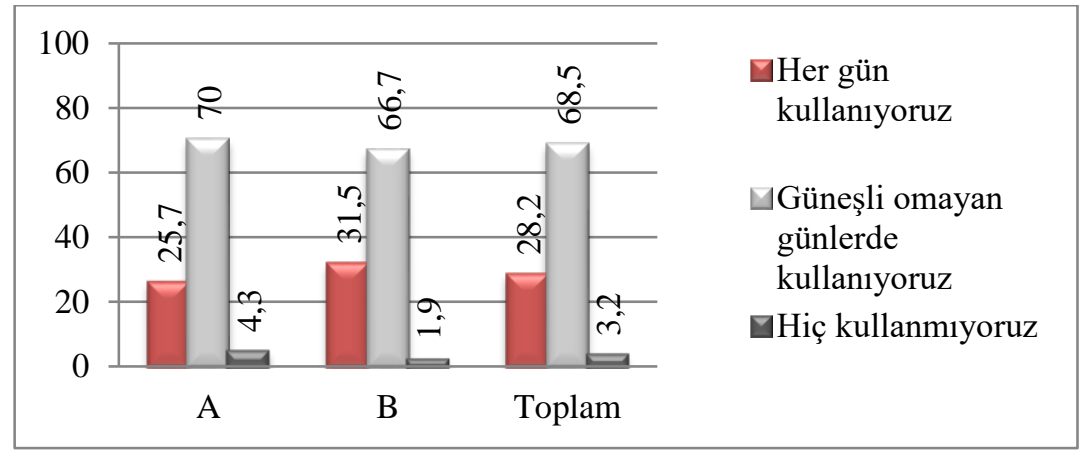

Şekil 14. 'Gün içerisinde sınıfınızda aydınlatma aracı kullanıyor musunuz?' sorusuna verilen cevapların grafiği

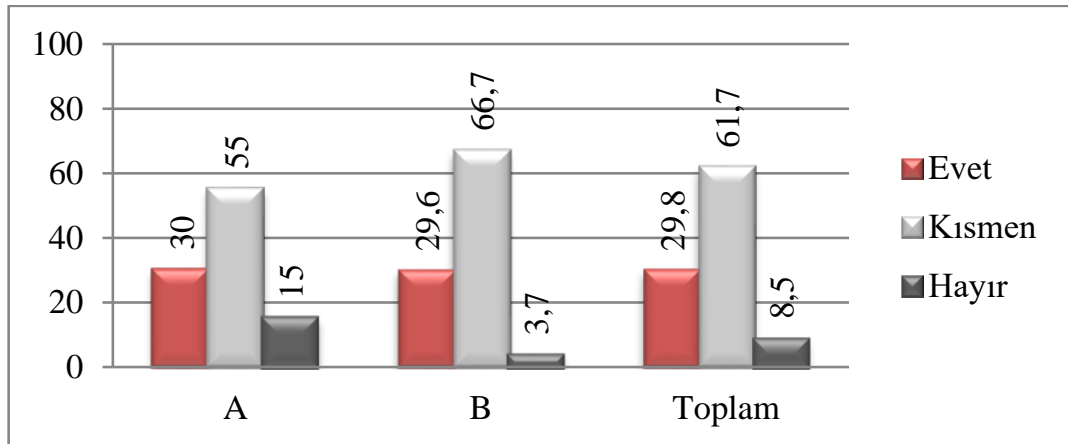

Şekil 15. 'Gün içerisinde yapay aydınlatmaya ihtiyaç duyuyor musunuz?' sorusuna verilen cevapların grafiği

Dersliklerin kış mevsimindeki gün ışığı miktarının sorgulandığı soruya karşılık öğretmenlerin çoğunluğu (\%83) kış mevsiminde de yeterince doğal aydınlatma sağlandığını ifade etmiştir (Şekil 16). 


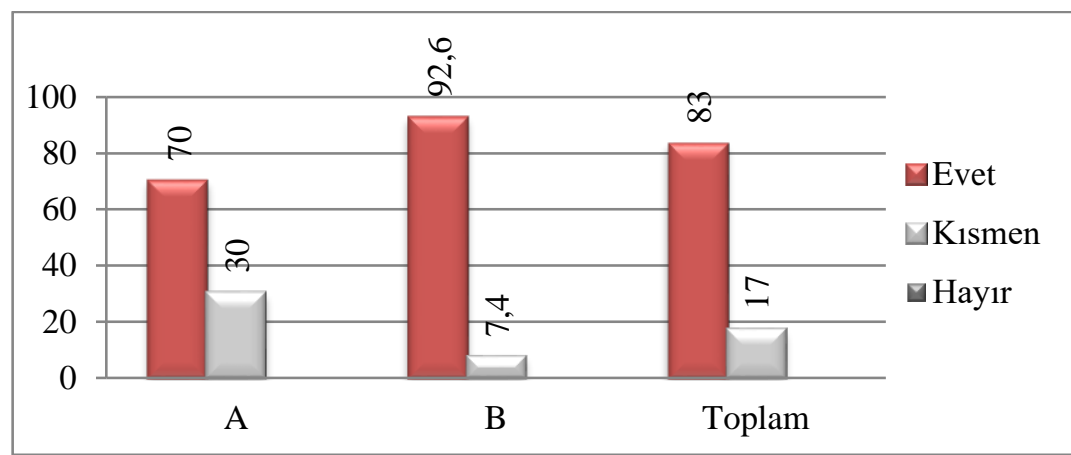

Şekil 16. 'Kış mevsiminde derslikler yeterince gün ışığı alıyor mu?' sorusuna verilen cevapların grafiği

Çalışma kapsamında iç mekandaki görsel konforun sorgulanması noktasında manzara ve gün ışığı özellikleri irdelenmiştir. Bu bağlamda her iki okulda kullanıcıların çoğunluğu dersliklerin manzarasından memnun olduğuna ilişkin görüş bildirmiştir. Okulların şehir merkezindeki kargaşadan uzakta ve kırsal olarak nitelendirilebilecek bir konumda yer almasının görsel açısından kullanıcı memnuniyetine olumlu yönde yansıdığı görülmektedir.

İç mekandaki etkin gün ışığı kullanımına yönelik anket verileri değerlendirildiğinde, öğrencilerin çoğunluğu güneşli olmayan günlerde dersliklerdeki gün ışığı düzeyini yetersiz bularak lamba yaktıklarını belirtmiştir. Öte yandan öğretmenler ise yapay aydınlatmaya kısmen intiyaç duyduklarını ifade etmiştir. Bu veriler doğrultusunda, gün ışığı kullanımının etkinliği açısından birtakım yetersizlikler olduğu sonucuna varılmıştır. Gün ışığının iç mekânda her noktaya ulaşabilmesi için mekân genişliği, pencere yüksekliğinin maksimum 2,5 katı olması gerekmektedir. Her iki okulda da derslikleri bu kurala göre değerlendirdiğimizde mekân derinliğinin 2,5 H kuralına göre belirlenmediği tespit edilmiştir. Dolayısıyla gün ışığının iç mekânda her noktaya homojen bir şekilde dağılması mümkün olmamaktadır.

Güneşlenme süresinin daha az olduğu kış aylarında dersliklerdeki doğal aydınlatma performansı sorgulandığında A ve B okulundaki öğretmenlerin sırasıyla \%70'i ve \%92,6'sı gün ışığının yeterli olduğunu belirtmiştir. İki okul öğretmenleri arasında ortaya çıkan bu oran farkı dersliklerin bulunduğu yönle yakından ilişkilidir. Bu bağlamda B okulu derslikleri güney cephede konumlandırılarak gün ışığından maksimum düzeyde faydalanması sağlanmıştır. Dolayısıyla doğal aydınlatma performansı açısından kullanıcıların memnuniyet düzeyinin daha yüksek olduğu tespit edilmiştir.

İki okul genelinde öğrencilerin çoğunluğu güneşli olmayan günlerde yapay aydınlatmaya intiyaç duyduklarını belirtirken, öğretmenlerin kış aylarında gün ışığı mikta- rını yeterli bulması kullanıcılar arasında bir görüş ayrıığını işaret etmektedir. Bu noktada öğrenciler ile öğretmenlerin anket sorularını farklı yorumlamış olma intimali bulunurken gün ışığının dersliklerde homojen bir dağılım göstermemesi sonucunda pencere kenarında oturmayan öğrenciler açısından memnuniyet düzeyinin daha düşük olduğu da düşünülebilir.

LEED sertifikası manzara ve gün ışığının etkin kullanımına ilişkin birtakım kriterler ortaya koymaktadır. Bu kriterler; manzaraya yönelik iç mekanla dış mekan arasında kesintisiz bir görsel algı oluşturulmasını, pencere ebatlarının mekân boyutlarıyla ilişkili olarak belirlenmesini ve çeşitli simülasyonlar aracılığıyla aydınlatma seviyelerinin ölçülmesini gerekli kılmaktadır. Bu bağlamda A okulunun bu kriterlerden puan aldığı fakat B okulunun alamadığı tespit edilmiştir.

\section{SONUÇLAR}

Eğitim yapılarında nitelikli ve kullanıcı odaklı mekanların oluşturulması, fiziksel konfor koşullarının yapıya entegre edilmesi ile mümkün olmaktadır. Bu bağlamda LEED sertifikasına sahip temel eğitim yapılarının iç mekân konfor koşullarının kullanıcı görüşleri doğrultusunda değerlendirilmesi amacıyla yapılan bu çalışmada aşağıdaki sonuçlara ulaşılmıştır:

- Dersliklerdeki hava kalitesi açısından kullanıcı memnuniyetinin büyük bir oranda sağlandığı görülmüştür.

- Kullanıcıların, kış mevsiminde dersliklerin soğukluğundan rahatsızlık duymasına karşılık genel anlamda diğer mevsimlerdeki ısıl performanstan memnun oldukları tespit edilmiştir. Bu noktada kullanıcıların cinsiyeti özelinde bir değerlendirme yapıldığında; erkek öğrencilerin dersliklerin kış mevsimindeki sıcaklığından rahatsızlık duyma oranının kız öğrencilere göre daha yüksek olduğu tespit edilmiştir. Öğretmenlerde ise ısıl konfor açısından cinsiyete bağıı bir değişim gözlenmemiştir. 
- Ders esnasında genel olarak öğrencileri rahatsız edecek boyutta bir gürültü düzeyi bulunmazken diğer mekanlardan gelen gürültünün öğretmenlerin bir kısmını rahatsız ettiği görülmüştür.

- Okullarda kullanıcıların büyük bir kısmının manzara özelliklerini olumlu bulduğu gözlemlenmiştir.

- Dersliklerin konumlandırıldığı yönün gün ışığının verimliliği noktasında kullanıcıların memnuniyet düzeyini önemli oranda etkilediği tespit edilmiştir. Bu bağlamda güney cephede bulunan dersliklerde doğal aydınlatma performansının arttığı görülmüştür.

- Anket verileri doğrultusunda, çalışmaya katııp görüş bildiren öğrenci ve öğretmenlerin iç mekan konfor düzeyini genel anlamda yüksek bulduğu saptanmıştır.

Genel bir değerlendirme yapacak olursak, doğru ve etkin bir şekilde uygulanan sürdürülebilir yaklaşımların fiziksel konfor koşulları ile birlikte kullanıcı memnuniyetini de arttırdığı görülmüştür. Özellikle dersliklerin doğru yönde konumlandırılmasının manzara ve gün ışığı özellikleri açısından kullanıcı memnuniyetini belirgin bir şekilde artııdığı tespit edilmiştir. Benzer şekilde dersliklerin başka mekanlarla mümkün olduğunca az çevrelenmesinin diğer mekanlardan gelen gürültüyü azalttığı ve bu sayede işitsel konforu arttırdığı görülmüştür. Ayrıca dersliklerde kişi başına düşen hacim miktarının iç hava kalitesi açısından kullanıcıların memnuniyet düzeyini önemli derecede etkilediği de anket verileri ile tespit edilmiştir. Dolayısıyla eğitim yapılarında en çok vakit geçirilen mekanlar arasında yer alan dersliklerin, kullanıcı sayısı göz ardı edilmeksizin boyutlandırılması gerekliliği böylece ortaya koyulmuştur.

Okulların sertifika puanları incelendiğinde konfor koşullarına ilişkin değerlendirmelerin anket verileriyle bazı noktalarda çeliştiği görülmüştür. Özellikle gün ışığı kullanımı açısından B okulu kullanıcılarının memnuniyet düzeyi yüksek olmasına karşın sertifika değerlendirmesine göre yetersiz olduğu tespit edilmiştir. Bu noktadaki yetersizliğin $B$ okulunda yapı kullanım aşamasındaki gerekli ölçümlerin yapılmamış olmasından kaynaklandığı düşünülmektedir. Ayrıca dersliklerdeki pencere boyutlarının iç mekân ile dış mekân arasında görsel sürekliliği sağlaması açısından yetersiz olduğu sonucuna da ulaşılmaktadır. Bu bağlamda bina değerlendirme sistemleri binaları birçok parametre açısından değerlendirmesine rağmen çalışma kapsamında elde edilen anket verileri, yapı kullanım aşamasındaki kullanıcı memnuniyet ölçütünün ne kadar önemli olduğunu göstermektedir. Ayrıca binalarda yapılacak olan sürdürülebilirlik değerlendirmelerinin kullanıcı görüşleri doğrultusunda yapılmasının kredi sonuçlarına önemli katkılar sağlayacağı düşünülmektedir. Bu bakımdan bina değerlendirme sistemlerinin, puanlamada ölçüt olarak kullandığı başııklara yapı kullanıcılarının görüşlerini de eklemeleri yönünde bir öneri geliştirilebilir.

Diğer tüm binalar gibi eğitim yapıları da öncelikli olarak kullanıcıların sağlığını ve konforunu önemsemek üzere tasarlanmalıdır. Özellikle günümüzde tüm dünyayı etkisi altına alan Covid-19 salgını, sağlıklı ve konforlu iç mekanlara duyulan intiyacı daha da arttırmıştır. Bu tür salgınlar neticesinde binaların sağlığımız üzerinde çok önemli etkilerinin olduğu daha iyi anlaşılmaktadır. Gelecekte de olabilecek her türlü salgına karşılık sağlığımızı tehdit eden değil, sürdürülebilir tasarım yaklaşımları doğrultusunda tasarlanan, insan sağlığını ve konforunu önceleyen binalar tasarlanmalıdır. Yapılan çalışma kapsamında binaların insan sağlığı üzerindeki etkilerine değinmek amaçlanmamış olsa da bu konu gelecek çalışmalar için önemli bir açılım sunmaktadır.

\section{TEŞEKKÜR}

Bu makale, Doç. Dr. Filiz TAVŞAN'ın danışmanlığında Zeynep YANILMAZ tarafından hazırlanan "Sürdürülebilir Temel Eğitim Yapılarında İç Mekan Konfor Koşullarının Değerlendirilmesi" başlıklı yüksek lisans tezinin verileri kullanılarak hazırlanmıştır.

\section{KAYNAKLAR}

Alkan, İ. (2010). Ofis Mekanlarında Işık ve Renk İlişkisinin Görsel Konfora Etkisi, Yüksek Lisans Tezi, Mimar Sinan Güzel Sanatlar Üniversitesi, İstanbul.

ASHRAE (2008). ASHRAE Handbook- HVAC Systemes and Equipment, American Society of Heating Refrigerating and Air-Condition Engineers, Inc., Atlanta.

Atmaca, İ., Yiğit, A. (2005). İklimlendirilen Ortamlar için Isıl Konforun Geçici Rejim Enerji Dengesi Modeli ile Değerlendirilmesi. Tesisat Mühendisliği Dergisi, 88: 61-71.

Balanlı, A. (2007). Yapı Elemanları III: Doğramalar, Yayınlanmamış Ders Notu, Yıldız Teknik Üniversitesi.

Boeri, A., Longo, D. (2013). Environmental Quality and Energy Efficiency: Sustainable School Buildings Design Strategies, International Journal of Sustainable Development and Planning, 8 (2): 140-157.

Ding, G.K.C. (2008). Sustainable Construction the Role of Environmental Assessment Tools. Journal of Environmental Management, 86: 451-464.

Erdede, S.B., Erdede, B., Bektaş, S. (2014). Sürdürülebilir Yeşil Binalar ve Serifika Sistemlerinin Değerlendirilmesi, 5. Uzaktan Algılama-CBS Sempozyumu, Ekim, İstanbul. https://www.kongresistemi.com/root/dosyalar/uzalcbs2014/221.pdf (Erişim Tarihi: 31.03.2021).

Ford, A. B. (2007). Designing the Sustainable School. The Images Publishing, Australia.

Gilman, R. (1992). Sustainability By Robert Gilman from the 1992 UIA/AIA Call for sustainable community solutions. https://www.context.org/about/definitions (Erişim Tarihi: 10.12.2019). 
Gökmen, H.S. (2012). Sürdürülebilir Okul Örneklerine Bir Bakış. Mimarlık Dergisi, 368: 53-58.

Hes, D. (2009). Take 8 Learning Spaces: The Transformation of Educational Spaces for the 21st Century, Eds: Clare Newton and Kenn Fisher, Digital Print Australia, Australia.

Höppe, P., Martinac, I. (1998). Indoor Climate and Air Quality. Internal Journal of Biometeorol, 42: 1-7.

Karadayı, T. T., Yüksek, İ., Tunçbiz, İ. (2017). İlkokul Binalarının Ekolojik Açıdan İyileştirilmesi: İstanbul Tuzla Tapduk Emre İlkokulu Örneği. Mehmet Akif Ersoy Üniversitesi Fen Bilimleri Enstitüsü Dergisi, 8 (1): 22-33.

Olson, S.L., Kellum, S. (2003). The Impact of Sustainable Buildings on Educational Achievements in K-12 Schools. Leonardo Academy Cleaner and Greener Program Report.

Owen, C., Dovey, K. (2008). Fields of Sustainable Architecture. The Journal of Architecture,13(1): 9-21.

Saka, İ. (2011). Sürdürülebilirlik Açısından İstanbul'da Bir Ofis Binasının LEED Sertifikalandırma Sistemi Kapsamında Değerlendirilmesi, Yüksek Lisans Tezi, İstanbul Teknik Üniversitesi, Fen Bilimleri Enstitüsü, İstanbul.

Schramek, E. (1999). Recknagel-Sprenger Schramek. Isıtma ve Klima Tekniği El Kitabı. TTMD, Ankara.

Sev, A. (2009). Sürdürülebilir Mimarlık. Yem Yayınları, İstanbul.

Sirel, Ş. (1994). Yapı Fiziği Konuları. Ders Notları, YFU.

Sözen, M.Ş. (2014). Aydınlatma Tasarımında Mimarın ve Elektrik Mühendisinin Rolü. http://www.emo.org.tr/ekler/2cf3f7ef9063075_ek.pdf (Erişim Tarihi: 07.05.2020).
Stumpf, B., Chadwick, D., Dowell, B. (2001). The Attributes of Thermal Comfort Ergonomic Criteria for the Design of a New Work Chair. https://www.project-inrichting.nl/pdf/Aeron-Attributes_of_thermal_comfort-Witteveen.pdf (Erişim Tarihi: 31.03.2021).

Tonguç, B., Özbayraktar, M. (2017). Sürdürülebilir Okul Öncesi Eğitim Yapılarının Sosyal ve Kültürel Sürdürülebilirlik Açısından İncelenmesi. Mimarlık ve Yaşam Dergisi, 2(1): 2746.

URL-1, (2021). https://www.usgbc.org/ (Erişim Tarihi: 19.05.2021).

URL-2, (2020). http://www.cihangir.k12.tr/kampuslerimiz/bahcesehir/ (Erişim Tarihi: 07.01.2020).

URL-3, (2020). http://www.arkiv.com.tr/proje/terakki-vakfiokullari-tuzla-tepeoren-kampusu/ (Erişim Tarihi: 07.01.2020)

Yüksek, İ., Mıhlayanlar, E., Tıkansak, T.E. (2015). Konut KulIanıcılarının İç Ortam Konfor Koşullarından Memnuniyetlerinin Tespitine Yönelik Bir Çalışma, 12. Ulusal Tesisat Mühendisliği Kongresi, Nisan, İzmir, 2141-2149.

Yüksel, N. (2005). Günümüz Kamu Kurumlarında Yapısal Konfor Koşullarının Tespit Edilmesine Yönelik Bir Çalışma. Uludağ Üniversitesi Mühendislik-Mimarlık Fakültesi Dergisi, 10(2): 21-31.

Zhang, H., Huizenga, C., Arens, E., Yu, T. (2006). Modeling Thermal Comfort in Stratified Environments. Center for Environmental Design Research, University of California at Berkeley. 